\title{
Research Agenda: The Relationship between Korean Foods and Avian Influenza (AI) \\ Kyoo-Man Ha
}

Department of Public Policy and Management, Pusan National University, Korea

\begin{abstract}
A series of AI (or H5N1-kind) viruses has frequently infected South Korea (hereinafter to be Korea) for almost the last 15 years. During winter, between 2016 and 2017, the H5N8 virus infected Korea again. Also, there was a recent breakout of the H5N6 virus in the region [1]. As a result, quarantine authorities have killed so many farm birds such as chickens and ducks. Further, AI has become transmissible to some mammals to include not only cats but also moose, and as a consequence, infected mammals were also killed. Fortunately, none of the AI virus has been known to be transmissible to humans in Korea yet.
\end{abstract}

Some researchers in Seoul National University in Korea fed kimchi, which is a traditional spicy pickled cabbage, to AI-infected chickens in 2005. Eleven (11) out of the 13 infected chickens (or about $85 \%$ of those infected chickens) recovered from the impact of AI virus. Those researchers said that they clearly observed the effects of kimchi, but failed to scientifically explain why [2]. Other researchers have continued to maintain that the AI virus will not infect or kill Koreans because of the apparent protective effects of Korean foods, not only kimchi, but also red ginseng and garlic.

In China, the H5N6 virus has infected not only its southern provinces but also its western provinces since 2013. As a result, there was serious poultry infection in the country. Further, the highly pathogenic H5N6 virus had infected a person in Sichuan Province in April 2014. The H5N6 virus continued to infect another person in Guangdong Province in December 2014. Then, another four people were infected by the H5N6 virus in Guangdong Province in December 2015 [3]. In short, the H5N6 virus has become transmissible to humans, in the case of China.

At that time, the World Health Organization (WHO) conducted an H5N6 risk assessment. As a result, the institution did not recommend special screening toward $\mathrm{H} 5 \mathrm{~N} 6$ virus. Nor did it recommend travel restriction to infected areas or countries. However, the WHO emphasized that the infection of $\mathrm{H} 5 \mathrm{~N} 6$ must be considered in diverse individuals, who show severe acute respiratory symptoms [4].

In summary, some Korean researchers have maintained that the AI virus is not yet classifiable as a zoonosis, apparently thanks to the effects of its traditional foods. On the other hand, some Chinese researchers have found that $\mathrm{AI}$ is a zoonosis. Additionally, the WHO admits the possibility of zoonosis to certain individuals. With all these in mind, it is necessary to research whether Korean foods can indeed protect or cure individuals from the effects of H5N6 or not. If Korean foods do not play a role in protecting or curing individuals from H5N6, the Koreans will have an opportunity to improve its extent of $\mathrm{AI}$ awareness (or at the very least, know how unscientifically wrong they have been). Otherwise, other nations could utilize extracts from certain Korean foods as AI vaccine to cure infected individuals. If this is proven, then this becomes a shortcut for the international community, in terms of finding the cure for AI.

\section{Competing Interests}

The author declares that he has no competing interests.

\section{Publication History:}

Received: January 31, 2017

Accepted: February 18, 2017

Published: February 20, 2017

\section{Keywords:}

Avian influenza, H5N6 virus, Zoonosis

\section{References}

1. Ministry of Agriculture, Food and Rural Affairs (MAFRA) (2017) Avian Influenza (in Korean).

2. Chazan D (2005) Korean dish 'may cure bird flu'. BBC News.

3. Centers for Disease Control and Prevention (CDC) (2016) Novel reassortant avian influenza A(H5N6) in Humans, Guangdong, China, 2015 Emerging Infectious Diseases, Vol. 22, No. 8.

4. World Health Organization (WHO) (2017) Human Infection with Avian Influenza A (H5N6) Virus - China.
${ }^{*}$ Corresponding Author: Dr. Kyoo-Man Ha, Department of Public Policy and Management, Pusan National University, Korea; E-mail: ha1999@hotmail.com

Citation: Ha KM (2017) Research Agenda: The Relationship between Korean Foods and Avian Influenza (AI). Int J Community Fam Med 2: 125. doi: https:// doi.org/10.15344/2456-3498/2017/125

Copyright: @ $2017 \mathrm{Ha}$. This is an open-access article distributed under the terms of the Creative Commons Attribution License, which permits unrestricted use, distribution, and reproduction in any medium, provided the original author and source are credited. 